\title{
Exploring the Relevant Skills Needed for the Digital Age Employees
}

\author{
Hanan Gouda \\ College of Management and Technology, Arab Academy for Science, Technology, \& Maritime Transport \\ Po.Box 1029 - Miami - Alexandria, EGYPT
}

\begin{abstract}
The aim of this study is to explore the relevant skills needed for the digital age employees in business. After reviewing prior studies and literature, it was recognized that technology changed the requirements of employment. Digital technology stimulated an effect on employment in a wide range of business industries, changing the laborforce requirements. A qualitative approach was used to provide deeper insights into the studies presented in the literature. The aim of the exploration was to validate the research variables and develop a proposed conceptual framework of the vital skills relevant in the digital age labor-market. Three focus groups were steered in this study. Each focus group contained seven participants who were managers in various companies in different business sectors in Cairo or Alexandria. The participants in each focus group were homogeneous. The managers were into groups according to their company's classification (local, multinational, and non-profit organization). The organizations were chosen based on a purposive sample and only organizations with a human resource department were invited to take part. According to the thematic analysis results, managers recruit graduates not only with technical skills, as represented by the degree obtained or the subjects that they took in college, but also with their employability skills: personal skills in business practices and digital media and information literacy. This study offered practical and academic contributions. The empirical evidences supported that technology has changed the requirements of employment, developing a proposed conceptual framework that recognizes the main skills needed in the digital age workforce.
\end{abstract}

Keywords: Digital Age, Employability, Hard Skills, Media Literacy, Soft Skills, Workforce.

DOI: $10.7176 / \mathrm{EJBM} / 12-2-07$

Publication date: January $31^{\text {st }} 2020$

\section{Introduction}

In contemporary markets worldwide, advancement in technology has progressed and dominated human life (Younes and Zoubi, 2015). Innovations in computing and telecommunication technologies are significantly affecting most of the areas of the economy, leading to the transformation acceleration in business (Fox, 2018). Accordingly, technological advancements have entirely reshaped the organizations by making their business processes highly integrated, restructured, and well run. Work (its content, its organization and design, its regulation and protection) is all undergoing great change in this digital age (Frey and Osborne, 2017). The impact of digitalization has changed the labor market requests and skills as well (Acemoglu and Restrepo, 2017).

Digital technologies have caused business operations to develop to a new level of quality and distinction (Corless et al., 2018). It provided solutions and enhancements towards the responsibility, accountability, efficiency, and delivery time of tasks. Technology allows flexibility in communication, making employees connect with each other straightforward, simple, and effortlessly anywhere at anytime, such as through electronic messages, teleconferencing, and co-working space (Terzioglu et al., 2017). Cloud technology lets data access, storage, and usage to be instantly reachable wherever and whenever (Acemoglu and Restrepo, 2017). Technology helps in keeping the business fully organized. Numerous applications, programs, and software help in building, delegating, tracking, reviewing, and assessing tasks (Fox, 2018). Moreover, these innovations are cost-effective in operating various business activities (Corless et al., 2018). According to the United Nation's Sustainable Development Goals Report (2018), digital technology has influenced employability. It allowed labor productivity to increase and the unemployment rate to decrease.

The influences of digital technologies have brought changes to the labor market (Rahmil, 2014). Certain occupations have vanished due to the absence of their necessity; others have become more demanded in the market. Moreover, additional job positions have transpired and increased. To perform these new jobs, the development of certain skills and know-hows are required (Walwei, 2016). According to research and prior studies, technologyintensive usages in businesses reduce the reliance on manual and routine tasks, shifting the skill composition toward cognitive and non-routine tasks. Thus, sets of proficiencies and services are required in the labor market (Terzioglu et al., 2017).

Digital technologies are one of the main drivers of the world economy today and their impact on the business market is a topic of continuous discussion (Fox, 2018; Acemoglu and Restrepo, 2017). Many studies investigated the labor market consequences of technological change. Research debates support the empirical relationship 
between the expansion of technology and the change of labor force requirements, decreasing middle-skilled jobs and increasing high skilled jobs (Acemoglu and Autor 2011; Messina et al., 2016). This association is well established for developed countries. However, the evidence is still scarce for emerging economies (Almeida et al., 2017). Hjort and Poulsen (2017) analyzed the impact of fast Internet arrival on Africa's labor market. They provided evidence that technology has changed the requirements of employment. Digital technology stimulated an effect on employment in a wide range of industries. For this reason, exploring the role of digital technology on the skill needed at work in a developing country is one of the essential contributions of this paper.

This study plans to investigate the impact of digitalization on the Egyptian labor market. Egypt has an immense potential labor market (with nearly 100 million people) that can benefit both global and local companies. According to the CIA world fact book (2018), over the next five years, around 3.5 million young Egyptians are projected to join the labor force. The State Information Service (2018) indicated that the government is seeking to develop programs to train youth to be ready for the contemporary market and improve their employability in order to reduce unemployment and improve living standards among workers.

\subsection{Research Objectives}

The digitalization in business has a prevalent impact on the market and labor force. Thus, current students (the future workforce) and potential employees that lack digital knowledge and skills will have difficulty to compete with others for employment since the skills in the workplace is continuously expanding (Almeida et al., 2017). Potential work force needs to develop their digital age literacy. Studies mentioned that technology literacy represent critical grounds for success in work field. The needed knowledge related to technology literacy can include effective communication, information analysis and interpretation, task management and priorities, problem solving, and other business related skills (Bughin et al., 2018). Thus, the main aim of this study is to identify the relevant skills needed by the digital age labor market relevant to the Egyptian business field. In order to achieve this aim, this research contains twofold objectives: (1) critically review relevant literature in order to identify the impact of digital technology antecedents supplementary on employment in the business industries; (2) explore and develop a rich understanding of the vital skills needed in order to make indiviudals employable in the digital age in Egyptian context through the use of qualitative approaches.

\section{Literature Review}

Academics, practitioners, and economists have long been interested in the effect of technological change on the labor market (Fox, 2018). This research has focused on how digital technology influences the skill acquisition of young workers in the business field.

\subsection{The Labor Market}

With the progression in technology, the process of business operations and functions are not stable or predictable these days. This allows the labor force to exist in a complex and uncertain market. Consequently, scholars recommend that: "they need to develop their own capacity to innovate, adapt to change, and manage instability" (Preda, 2002, p.80). There are several market dynamics that impact labor market, such as: "demographic development, the competitiveness of the nation economy, globalization and last but not the least is technological change or digitalization" (Walwei, 2016, p.2). Research showed that the technological revolution, however, is of great significance. The technological transformation is a prevailing factor out of the four listed (Messina et al., 2016). It is the key determinant of economic growth and productivity (Walwei, 2016).

Technology advancement generated and increased business usage of: artificial intelligence, autonomous vehicles, big data analytics and clouds, custom manufacturing (3D printing), Internet, digital devices, robots, social media and platforms, and many more technological elements (Acemoglu and Restrepo, 2017). These elements are: "drastically changing prospects for the type of jobs that will be needed in the future and how, where and by whom they will be done" (The Organization of Eastern Caribbean States, 2016). The burst of technology constantly evokes debates on whether it serves as an opportunity to create many new jobs on the market or to diminish existing jobs (Hjort and Poulsen, 2017). Overall, the digital transformation has both positive and negative impact on the labor market, affecting: "job creation and job loses, expectation for the demanded skills for the future and the way labor market respond to these requirements and changing working conditions" (European Parliament, 2016, p.6). Digitalization and Job Creation: The digitalization era brought changes to the labor market (Hagel et al., 2017). It created demand for some jobs and decreased it for others (Kucera, 2017). There is a continuing tendency of technological professions to be in strong demand (Acemoglu and Restrepo, 2017). Nowadays, most in-demand and top paid jobs are related to the positions that use advanced technology, such as: data scientists and engineers (people who design and build programs to create large data sets), analytics leader (people who analyze data to create long-term and short-term business strategies for the generation of revenue and the efficiency in operations), social marketing executive (people who performs market analysis, formulates and implements marketing plans, and engage in customers relationship management through social media programs and online functions) and many 
others jobs in technology related fields (Almeida et al., 2017). These professions exist in various market fields, for example, in education, healthcare, law, finance, customer services, etc. (Bureaus of Labor Statistics, 2015).

Digitalization and Low-Skilled Jobs: Digitalization not only created strong demand for technological positions and jobs, but it reduced the demand for routine and low-skilled jobs (Frey and Osborne, 2017). For example, with technology, retail cashiers are being replaced with digital self-checkout options; there is no need for newspaper deliveryman if people can read news online; travel agent are becoming defunct sense people can use Google and other online search engines to book and plan their trip; there is declining demand towards postal-services worker as automated sorting systems and online telecommunication services exist and made communication instantaneous and rapid (Almeida et al., 2017). Besides reducing routine and low-skilled jobs, digitalization also influenced certain routine and low-skilled jobs' conditions and approaches (Fox, 2018). For example, with technology (the internet, digital devices, and the ease of mobile payments, creation of applications and online platforms), there is no need for dispatchers, as orders can be taken online. With the usage of the Internet and its applications, shared economy prevailed and transpired. It effectively connected people who have underutilized assets with people who want to make use of these assets (assets range from large goods, such as cars and houses, to products such as tools, toys and clothing) (Hamari et al., 2016).

Digitalization and New Jobs: Smartphones was first launched in the market in 2007. Nowadays, almost half of the world's adult population has a smartphone. This phenomenon allowed digitalization to create new jobs in the market (Association of Southeast Asian Nations, 2016). For example, there is a huge demand for mobile applications, which leads to: "a blooming market for app developers" (Hallett and Hutt, 2016). Social Media Executive is another profession that emerged. Social media platforms have become very popular among individuals, making it a prevalent tool to promote and popularize brands allowing them to efficiently reach and communicate with customers (Kotler and Armstrong, 2017). Cloud computing specialist is another job that emerged (Burke, 2017). Other jobs that digitalization created are: Market Research Data Miner, App designer, Blogger, Chief Listening officer, YouTube content creator, Driverless car engineer, Drone operators, Uber driver etc. (Almeida et al., 2017). Accordingly, these new occupations require certain set of skills to perform the jobs successfully (Fox, 2018; Frey and Osborne, 2017).

\subsection{Employability Skills: Hard and soft skills}

The importance of employability skills is increasingly emphasized in recent times (Suarta et al., 2017). Employability skills refer to a collection of necessary skills, capabilities, powers, and knowledge that is required for success in the modern workplace (Rahmil, 2014; Walwei, 2016). Suarta et al. (2017) stated that there are employability skills that are considered essential credentials for many job positions. The American Management Association (2010) stated that critical thinking and problem-solving, creativity and innovation, collaboration, and communication skills are becoming increasingly important in today's global economy. Furthermore, in the digital age, many research proved that digital media literacy is vital for employment (Grundke et al., 2018).

It is known that technology: "make certain forms of human labor unnecessary of economically uncompetitive and create demand for new skills" (Manyika et al., 2013, p.15). Digitalization influenced employees' hard and soft skills that are in-demand and relevant for the current labor market (Hagel et al., 2017). Today, most companies do not need some skills that were required in the past to get a respectable job (Kucera, 2017). In this new era, many research show that the digital age has formed newly emerged occupations that require a different set of skills. There are certain combinations of hard and soft skills needed to successfully perform tasks (Fox, 2018; Patacsil et al, 2017).

The Organization for Economic Co-operation and Development (2015) claimed that the development of information and communications technology (ICT) industry leads to the increased demand of some divisions of ICT skills, such as: "ICT generic skills (ability to use information and communication technologies on the daily basis such as using software and applications, sending emails etc.), ICT specialist skills (such as ability to program software, develop and design applications, ability to manage networks etc.) and ICT complementary skills (social media marketing, communications on social networks, present brand products on online platforms etc.)."These skills are a necessity in the work field in many businesses. Reports indicate that businesses in the digitalization era embrace technologies to catch up with the market and benefit from its productivity and innovations (Grundke et al., 2018). Thus, companies need "digitally skilled employee for increasing productivity, sales, offering better services for the clients and generating revenue" (Information and Communications Technology Council, 2016, p.7).

Brooks (2016) claimed that the needed hard skills these days needed by future employees include: "programming and application development, business intelligence and analytics, web development, database administration, middleware and integration software, social media management, cloud and distributing computing". Walwei (2016) explained that these mentioned hard skills are in demand. Brooks (2016) argued that not having any of these mentioned skills reduces the chances of finding a job almost to zero.

Kotler and Armstrong (2017) mentioned that social media has dominated the business and consumer market. It is 
changing the way companies do business (Fox, 2018). Thus, social media literacy is significant to grasp in the current era. It is important to understand how these tools work, using them effectively for business purposes (McDougall et al., 2018). Social media literacy is one of the top five skills that companies look for when hiring (World Economic Forum, 2016). Research showed that employees with social media knowledge and the comprehension of digital devices have a clear advantage over candidates that have limited experience (Kishokumar, 2016). In the digital age, employees can obtain better jobs and advance their careers by proving social media competency (Durga, 2015; Jagero, 2014).

When it comes to soft skills, according to World Economic Forum (2016), there are ten vital skills that companies are looking for in potential employees. Based on this report, the potential employee is expected to be able to solve complex problems; to conduct critical thinking; to be able to have wholesome Judgment and fast decision making capabilities (cognitive flexibility); to have negotiation skills; to be a good communicator in order to coordinate well with others; people management skills are required (emotional intelligence); to remain an active listener; to be creative in rational and behaviors; to pursue for quality in productivity; and service orientation skills are one of the key skills needed. The World Economic Forum (2016) indicated these skills are the highest demand in 2020 labor market.

Berger (2016) explained that soft skills are not so relevant and important for information technology industry (industries concentrated on the technologies and their development of mobile applications, data mining and analysis, cloud computing, web development, etc.). These skills are given high values regarding industries related to consumer services or retail the focus on personal relationship management, such as: restaurants, consumer services and professional training and coach (Kotler and Armstrong, 2017). These industries require lots of communication, interaction and negotiation with customers, so the soft skills are a must in these industries (Soloman, 2017).

Business skills are a necessity in order to have sustainable operations in the market (Jibuti et al., 2017). Human resources and strategic officers will seek employees holding certain skills necessary to run day-to-day business operations (World Economic Forum, 2016). As more companies adopt flat organization structures, there is demand for people who understand basic business principles (Mazzarol and Reboud, 2006). Reports show that it is beneficial to hire individuals that understand how businesses operate (Jibuti et al., 2017). Prior empirical evidences show that when potential job candidates show hiring managers that they are acquainted with the basic functions of different departments (marketing, sales, finance, etc.) within the company, they become a significantly more attractive job candidate (Feng, 2018). Another study indicated that employees capable of strategic planning are valued in the workforce (Alencar et al., 2017). Strategic planning is an important business activity because it allows the recognition of proper development of company's future performance, strategy or direction regarding various industry decisions on allocations of resources of capital and people (Gluck et al., 1980).

Based on this literature review, the researchers concluded that the digital age changed the needed skills individuals should hold to become attractive job candidates. What skills should an individual look to focus on and develop to succeed in the digital age can be categorized into two groupings: Business Know-how (knowledge of business processes and operations in an industry) and Digital Know-how (knowledge on the usage of technology and communication platforms and devices). Thus, this two research questions emerged: (RQ1) what are the needed Business Know-hows for the digital age employees; (RQ2) what are the needed Technology Know-hows for digital age employees.

\section{Methodology}

A qualitative approach was used to provide deeper insights into the studies presented in the literature. The aim of the exploration was to validate the research variables and develop the proposed conceptual framework, through an interpretivism perspective. According to the literature, there are voluminous skills that can be sought among potential candidates for employment. Knowledge work tasks are usually dominated by intellectual demands, technical know-how, creativity, interaction, mobilization, networking, and innovation. Thus, the research needed to downscale and identify the relevant skills needed in the Egyptian content.

The conduction of focus groups operated as a tool for the research variables validation. Prior studies stated that focus groups are useful in adapting and developing models and surveys in different environment settings (Saunders and Townsend, 2016; Bryman, 2016). The researcher used this method in order to gain a clearer focus on the main focal skills needed among employees in the workforce.

Three focus groups were steered in this study. Each focus group contained seven participants who were managers in various companies in different business sectors. The participants in each focus group were homogeneous. The managers were into groups according to their company's classification (local, multinational, and non-profit organization). In the focus groups, the managers discussed the employability of graduates. In this research, employability refers to: "a set of skills, knowledge and personal attributes that make an individual (graduates) more likely to gain employment and be successful in their chosen occupations, which benefits themselves, the workforce, the community and the economy" (Saunders and Zuzel, 2010). The questions directed 
to the managers were regarding the vital skills needed in the workplace. The questions referred to the "Employability Skills Framework", by Yorke and Knight (2006). This framework consists of personal qualities, core skills, and process skills. Each skill groups made up of a number of aspects (Table 1). The researchers asked the respondents to explain which skills under the employability aspects do they seek when hiring individuals' in their company. The discussions also reflected the impact of technology in the $21^{\text {st }}$ century workplace.

The participants in the focus groups signed a consent form to participate in the study. The focus groups that were conducted were recorded for forthcoming analysis. The researcher analyzed the data using thematic analysis. According to the identified themes, units derived from the patterns that occurred during the conversations, the proposed conceptual framework was developed.

Table 1. List of Employability Aspects

\begin{tabular}{|l|l|l|}
\hline \multicolumn{1}{|c|}{ Personal Qualities } & \multicolumn{1}{c|}{ Core Skills } & \multicolumn{1}{c|}{ Process Skills } \\
\hline Self awareness & Reading Effectiveness & Computer Literacy \\
Self confidence & Information Retrieval & Commercial Awareness \\
Independence & Language Skills & Political Sensibility \\
Emotional Intelligence & Self Management & Ability to work cross culturally \\
Adaptability & Critical Thinking & Applying media technology \\
Stress tolerance & Creativity & Coping with complexity \\
Initiative & Listening & Teamwork \\
Willingness to Learn & Written Communication & Prioritizing \\
Reflectiveness & Oral Presentation & \\
& Explaining & \\
& Global Awareness & \\
\hline
\end{tabular}

Source: Yorke and Knight (2006) “Embedding employability into the curriculum”

\section{Qualitative Results}

The studied population in this research is Egyptian employers of local, multinational, and/or nonprofit companies in Cairo and Alexandria, operating in various business fields. The organizations were chosen based on a purposive sample and only organizations with a human resource department were invited to take part. The following table (Table 2) illustrates the socio-demographic traits of the participants' involved each focus group.

Table 2. The Focus Group's Participants' socio-demographic traits

\begin{tabular}{|c|c|c|c|c|c|c|c|c|c|}
\hline \multirow[t]{2}{*}{$\begin{array}{l}\text { Focus } \\
\text { Group }\end{array}$} & \multirow[t]{2}{*}{ No. of Participants } & \multicolumn{4}{|c|}{ Company Classification } & \multicolumn{2}{|c|}{ Gender } & \multicolumn{2}{|c|}{$\begin{array}{l}\text { Year of } \\
\text { Experience } \\
\text { in the } \\
\text { Company }\end{array}$} \\
\hline & & $\begin{array}{l}\text { Finance } \\
\text { Industry }\end{array}$ & $\begin{array}{l}\text { Governmental } \\
\text { Industry }\end{array}$ & $\begin{array}{c}\text { Educational } \\
\text { Industry }\end{array}$ & $\begin{array}{c}\text { Retail } \\
\text { Industry }\end{array}$ & Male & Female & $<5$ & $5<$ \\
\hline 1 & 7 (local org.) & 4 & 1 & 2 & 0 & 4 & 3 & 1 & 6 \\
\hline 2 & 7 (multinational org.) & 2 & 0 & 2 & 3 & 6 & 1 & 1 & 6 \\
\hline 3 & 7 (nonprofit org.) & 0 & 6 & 1 & 0 & 1 & 6 & 5 & 2 \\
\hline \multicolumn{2}{|c|}{ Sub Total } & 6 & 7 & 5 & 3 & 11 & 10 & 7 & 14 \\
\hline \multicolumn{2}{|c|}{ Percentage } & $29 \%$ & $33 \%$ & $24 \%$ & $14 \%$ & $52 \%$ & $48 \%$ & $33 \%$ & $67 \%$ \\
\hline
\end{tabular}

Source: own work.

According to the mangers' opinions in the Egyptian market, they want to recruit graduates not only with technical skills, as represented by the degree obtained or the subjects that they took, but also with their employability skills. According to the employability element that they mentioned, the researchers classified two broad domains of skills, competencies, values and/or attributes: (1) personal skills in business practices (2) digital media and information literacy. Each competency consists of a number of skill attributes. Table 3 and Table 4 illustrate the frequency of the mentioned skills and the implication. With these insights, the proposed framework (Figure 1) was developed.

According to the managers in Egypt, the relevant personal skills in the business practice are: self-efficacy (technical skills), self-monitoring, tolerance of ambiguity, originality, coping strategy, achievement importance, teamwork, and communication skills. Thus, the first research question was answered, (RQ1) what are the needed Business Know-hows for the digital age employees? According to the managers, when it comes to digital media and information literacy, the relevant skills are: usage of digital tools, internet usage in business practice, internet information search, ICT communication, and digital media content creation. Thus, the second research question 
was answered, (RQ2) what are the needed Technology Know-hows for digital age employees.

Table 3. Relevant Skills Needed for the Digital Age Employees in Business (Business Know-hows for the digital age employees)

\begin{tabular}{|c|c|c|}
\hline $\begin{array}{l}\text { Personal skills in the } \\
\text { business practice }\end{array}$ & Managers explanation of the needed skill in Business & $\begin{array}{l}\text { Frequency of skill } \\
\text { mentioned by managers }\end{array}$ \\
\hline $\begin{array}{c}\text { Self-Efficacy } \\
\text { (Technical Skills) }\end{array}$ & $\begin{array}{l}\text { "Employees should have the ability to successfully complete a } \\
\text { specified task". }\end{array}$ & $21 / 21$ \\
\hline Self-Monitoring & $\begin{array}{l}\text { "Employees should observe and control his/her expressive } \\
\text { behavior for the purpose of managing a desired appearance". }\end{array}$ & $10 / 21$ \\
\hline Tolerance of Ambiguity & $\begin{array}{l}\text { "Employees should be able to adapt to the dynamic work } \\
\text { environment, having the openness toward stimuli that are less } \\
\text { than clear, puzzling, or indefinite". }\end{array}$ & $18 / 21$ \\
\hline Originality & $\begin{array}{l}\text { "Employees should be characterized by behaviors that exhibit } \\
\text { creativity, individuality, and spontaneity". }\end{array}$ & $17 / 21$ \\
\hline Achievement Importance & $\begin{array}{l}\text { "Employees need to attain competence and have work success } \\
\text { as a priority in accordance with social standards". }\end{array}$ & $6 / 21$ \\
\hline Teamwork & $\begin{array}{l}\text { "Employees hold positive affect toward working in teams. They } \\
\text { should be able to get along with other and be in harmony when } \\
\text { in group work". }\end{array}$ & $20 / 21$ \\
\hline Communication Skills & $\begin{array}{l}\text { "Employees communicate with the use of reason and logic } \\
\text { thinking to be persuasive". }\end{array}$ & $18 / 21$ \\
\hline Coping Strategy & $\begin{array}{l}\text { "Employees are able to deal with stressful situation by taking } \\
\text { direct action to solve the problem in an objective manner". }\end{array}$ & $17 / 21$ \\
\hline
\end{tabular}

Source: own work.

Table 4. Relevant Skills Needed for the Digital Age Employees in Business (Technology Know-hows for digital age employees)

\begin{tabular}{|c|c|c|}
\hline $\begin{array}{c}\text { Digital Media and } \\
\text { Information Literacy }\end{array}$ & Managers explanation of the needed skill in Business & $\begin{array}{c}\text { Frequency of skill } \\
\text { mentioned by managers }\end{array}$ \\
\hline Digital Tools Usage & "Employees are able to use various media and ICT Devices". & $21 / 21$ \\
\hline $\begin{array}{c}\text { Internet Usage in } \\
\text { Business Practice }\end{array}$ & $\begin{array}{l}\text { "Employees are able to use the Internet with an emphasis on its } \\
\text { usefulness in learning information related to the business } \\
\text { practices". }\end{array}$ & $21 / 21$ \\
\hline Internet Information & $\begin{array}{l}\text { "Employees' have the knowledge and ability to find information } \\
\text { on the web (Ability to Locate/Access Information)". }\end{array}$ & $21 / 21$ \\
\hline Search & $\begin{array}{l}\text { "Employees are able to use digital media for communication } \\
\text { interactivity with the emphasis of two-way flow of information" }\end{array}$ & $21 / 21$ \\
\hline Content Creation & $\begin{array}{l}\text { "Employees are able to create Media Content - blogs, emails, } \\
\text { posts, etc." }\end{array}$ & $10 / 21$ \\
\hline
\end{tabular}

Source: own work. 


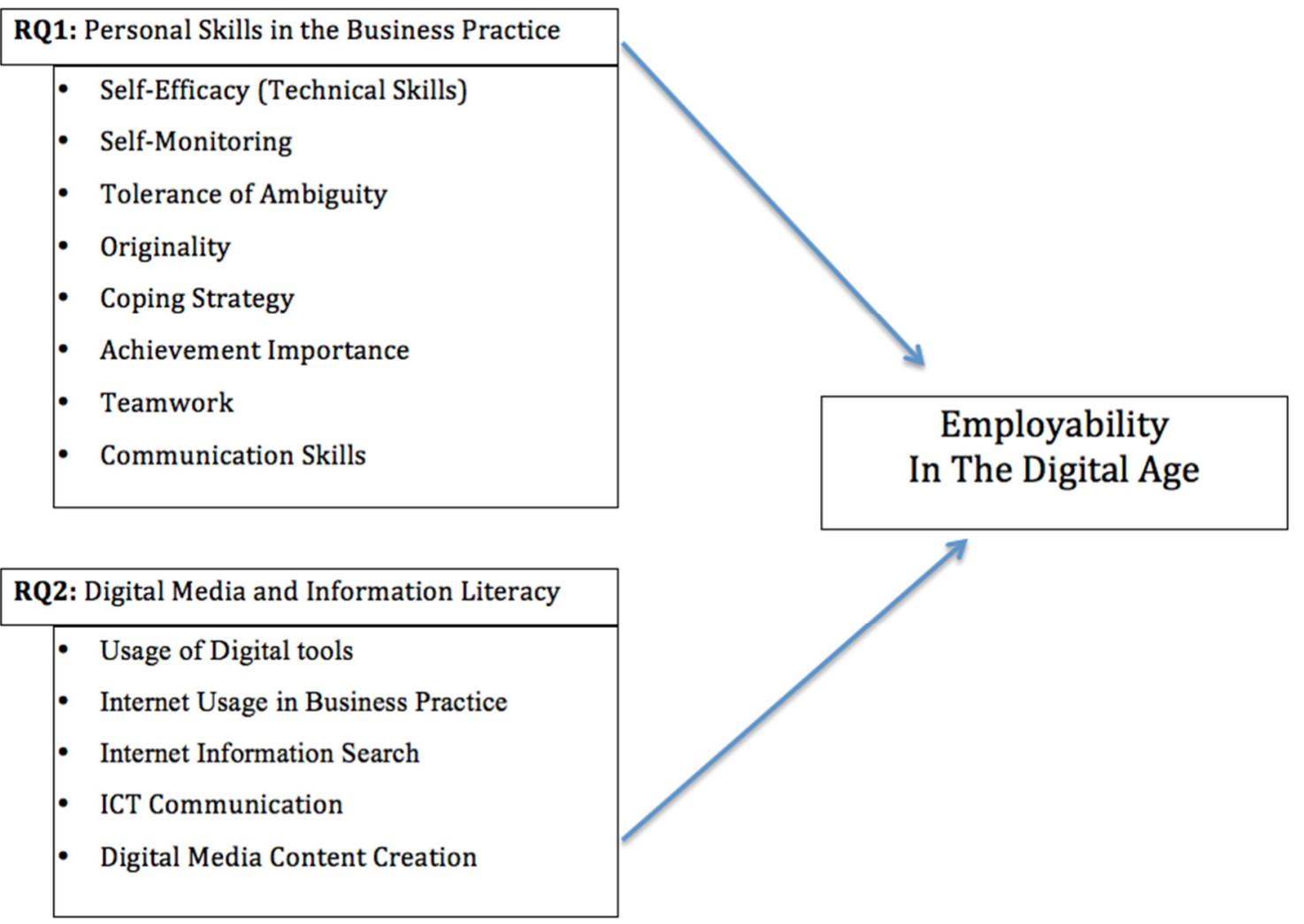

Source: own work.

Figure 1: Proposed Conceptual Framework

\section{Research Discussion and Conclusion}

The aim of this study is to explore the relevant skills needed for the digital age employees in business. In order to achieve this aim, this research contains twofold objectives: to critically review relevant literature in order to identify the impact of digital technology antecedents supplementary on employment in the business industries; and to explore and develop a rich understanding of the vital skills needed in order to make indiviudals employable in the digital age in Egyptian context through the use of qualitative approaches.

To achieve the first objective of this study, the researchers reviewed various prior studies and literature. According to the secondary research, it was recognized that technology changed the requirements of employment (Almeida et al., 2017). Digital technology stimulated an effect on employment in a wide range of business industries, changing the labor-force requirements (Brooks, 2016; Fox, 2018). To become employable in the digital age, potential employees need to hold certain knowledge. Knowledge involves two strongly inter-linked but different components: content and skills (Almeida et al., 2017). Content refers to the technical skills needed in the job. It can include facts, ideas, principles, evidence, and descriptions of processes or procedures (Fallow and Stevens, 2000). Intellectual skills include critical thinking and problem solving, creativity and innovation, collaboration, and communication skills (Fallow and Stevens, 2000). Furthermore, in the digital age, many research proved that digital media literacy is vital for employment (Grundke et al., 2018). These knowledge and skills are a necessity in the work field in many businesses to catch up with the market and benefit from its productivity and innovations (Brooks, 2016). Based on the review of the literature, two main research questions emerged: what are the needed Business Know-hows for the digital age employees; what are the needed Technology Know-hows for digital age employees.

To achieve the second objective of this study, and answer the research questions, a qualitative approach was used. The aim of the exploration was to validate the research variables and develop a proposed conceptual framework of the vital skills relevant in the digital age labor-market. Three focus groups were steered in this study. Each focus group contained seven participants who were managers in various companies in different business sectors in Cairo or Alexandria. The participants in each focus group were homogeneous. The managers were into groups according to their company's classification (local, multinational, and non-profit organization). The organizations were chosen based on a purposive sample and only organizations with a human resource department were invited to take part.

The data gathered from the focus groups were analyzed using the thematic analysis. The results of the research analysis indicted that there are two categories of knowledge and skills needed in the digital age: Personal Skills in 
the Business Practice and Digital Media and Information Literacy. According to the managers in Egypt, the relevant personal skills in the business practice are: self-efficacy (technical skills), self-monitoring, tolerance of ambiguity, originality, coping strategy, achievement importance, teamwork, and communication skills. When it comes to digital media and information literacy, the relevant skills are: usage of digital tools, Internet usage in business practice, internet information search, ICT communication, and digital media content creation. Based on these outcomes, the research questions were answered.

\subsection{Research Contribution}

This study contributed to the academic and practical field. Practically, this study developed empirical evidence that showed digital technologies has changed the composition of skills among workers. It has become one of the main drivers in the work field. Consequently, future employees need to advance their skills, focusing on both obtaining the needed technical skills (whether soft or hard skills) and developing their digital media and information literacy.

Many studies in the developed countries investigated the labor market consequences of technological change. Research debates support the empirical relationship between the expansion of technology and the change of labor force requirements, decreasing middle-skilled jobs and increasing high skilled jobs (Acemoglu and Autor 2011; Messina et al., 2016). However, the evidence is still scarce for emerging economies. Thus, this study contributed academically by filling in this academic gap, providing empirical evidence that technology has changed the requirements of employment in developing nations, specifically Egypt. Furthermore, this study developed a proposed conceptual framework that recognizes the main skills needed in the digital age workforce. Accordingly, future studies can use this model as their base in other contexts.

\subsection{Research Limitation}

This study had several limitations. The first was the small size of the sample and the fact that participants were in certain area of Cairo and Alexandria. Hence, the results may not be generalized or accurate regarding other cities in Egypt. The focus was on business field, neglecting the medical and engineering field. The present study needs to be supported by quantitative research that assesses the range of suggested antecedents as well as the overall model that was suggested. Finally, this study only focused on the managers' viewpoints not the employees that exist and work in the market.

\section{References}

Acemoglu, D. and Autor, D.H. (2011). Skills, Tasks and Technologies: Implications for Employment and Earnings. in O. Ashenfelter and D. Card, Handbook of Labor Economics, 4B, Amsterdam: North Holland.

Acemoglu, D., and Restrepo, P. (2017). Robots and jobs: Evidence from US labor markets. NBER Working Paper No. 23285 (Cambridge, MA, National Bureau of Economic Research)

Alencar, Marcelo Hazin, Luiz Priori Jr., and Luciana Hazin Alencar. (2017). Structuring objectives based on valuefocused thinking methodology: Creating alternatives for sustainability in the built environment. Journal of Cleaner Production, 156, 62-73

Almeida, R.K. and Poole, J.P. (2017). Trade and labor reallocation with heterogeneous enforcement of labor regulations. Journal of Development Economics, 126, 154-66

American Management Association (AMA). (2010). Executives say the 21st century requires more skilled workers. Retrieved June 17,2018, from: http://www.p21.org/news-events/press-releases/923-executives-saythe-21st-centuryrequires-more-skilled-workers

Association of Southeast Asian Nations (2016). Human Capital Outlook. Regional Community Briefing, 1-7.

Berger, G. (2016). Data Reveals The Most In-demand Soft Skills Among Candidates. Retrieved from LindedIn on December 2018: https://business.linkedin.com/talent-solutions/blog/trends-and-research/2016/mostindemand-soft-skills

Brooks, C. (2016). What Employers Want: 38 In-Demand Skills. Retrieved from Business News Daily on January 17, 2019: http://www.businessnewsdaily.com/5686-the-mostin-demand-career-skills.html

Bughin, J., Hazan, E., Lund, P., and Dahlström, P. (2018). Skill shift automation and the future of the workforce. McKinsey Global Institute press

Bureau of Labor Statistics. (2015). Occupations with the most job growth. Retrieved from Bureau of Labor Statistics on January 2019 from: https://www.bls.gov/news.release/ecopro.t06.htm

Burke, Z. (2017). 10 Jobs That Didn't Exist 10 Years Ago. Retrieved from Digital Marketing Institute on December 2018: https://digitalmarketinginstitute.com/blog/10-jobs-didnt-exist-10-years-ago

Corless, K., De Villers, L., and Garibaldi, C. (2018). Tech Trends 2018: The symphonic enterprise. Deloitte University Press

Durga, (2015). How social media gives you competitive advantage. Indian Journal of Science and Technology, $8(4), 90-95$. 
Fallow, S. and Stevens, C. (2000). Integrating key skills in higher education: employability, transferability, and learning. London UK/Sterling VA: Kogan Page/Stylus

Fox, S. (2018). Cyborgs, Robots and Society: Implications for the Future of Society from Human Enhancement with In-The-Body Technologies. Technologies. 6(50), 1-11

Frey, C.B. and Osborne, M.A. (2017). Future of employment: How susceptible are jobs to computerization? Technological Forecasting and Social Change, 114, 254-280

Gluck, Frederick W., Stephen P. Kaufman, and A. Steven Walleck. (1980). Strategic management for competitive advantage. Harvard Business Review, 108,154-61.

Hallett, R., and Hutt, R. (2016, June). 10 jobs that didn't exist 10 years ago. Retrieved from World Economic Forum on December 2018:https:/www.weforum.org/agenda/2016/06/10-jobs-that-didn-t-exist-10-yearsago/

Heerwagen, J.,K., Kampschroer, et al. (2004). Collaborative knowledge work environments. Building Research and Information, 32(6), 510-528.

Heming Feng. (2018). Case Study Research on Strategic Management of Alpha Company. Journal of Human Resource and Sustainability Studies, 6, 61-80

Hjort, J. and Poulson, J. (2017). The Arrival of Fast Internet and Skilled Job Creation in Africa. unpublished manuscript, Columbia Business School.

Hjort, Jonas and Jonas Poulson (2017). The Arrival of Fast Internet and Skilled Job Creation in Africa. unpublished manuscript, Columbia Business School.

Information and Communications Technology Council, (2016). Retrieved on December 2018: DIGITAL TALENT https://www.ictc-ctic.ca/wpcontent/uploads/2016/03/ICTC_DigitalTalent2020_ENGLISH_FINAL_March2016.pdf

Jagero, N. (2014). Impact of access to social media on employee productivity and organisational performance at Econet Wireless Zimbabwe. International Journal of Knowledge and Research in Management \& ECommerce. 4(1), 20-31.

Jibuti, M., Gvelesiani, R., Gelashvili, S. (2017). Fundamentals of Business Administration. Pablisher house Universal ISBN 978-9941-17-778-1

John Hagel, Jeff Schwartz, and Josh Bersin, (2017). Navigating the future of work. Deloitte University Press.

Juho Hamari, Mimmi Sjöklint. Antti Ukkonen (2016). The sharing economy: why people participate in collaborative consumption. Journal of the Association for Information Science and Technology, 67(9), 20472059

Kucera, D. (2017). New automation technologies and job creation and destruction dynamics. Employment Policy Brief (Geneva, ILO).

Lee, J. (2014). 6 Human Jobs That Computers Will Never Replace. Retrieved from Make on January 17, 2019 Use of: http://www.makeuseof.com/tag/6-human-jobscomputerswill-never-replace/

Manyika, J., Cabral, A., Moodley, L., Moraje, S., Yeboah-Amankwah, S., Chui, M., and Anthonyrajah, J. (2013). Lions go digital: The Internet's transformative potential in Africa.

Mazzarol, Tim, and Sophie Reboud. (2006). Strategic Management in Small Firms: Developing a Conceptual Framework. Paper presented at the 20th Annual Australia \& New Zealand Academy of Management (ANZAM) Conference, Rockhampton, Australia.

McDougall, J. Readman, and R. Philip Wilkinson (2018). The uses of (digital) literacy. Journal Learning, Media and Technology, 43(3).

Messina, J. Pica, G., and Ovied0, A. (2016). The polarization hypothesis in Latin America: how demand forces are shaping wage inequality? Unpublished manuscript. Inter-American Development Bank.

Mohammad Bani Younes, and Samer Al-Zoubi (2015). The Impact of Technologies on Society. Journal of Humanities And Social Science, 20(2), 82-86

Noon, M.B.P. (2007). The realities of work: experiencing work and employment in contemporary society. New York, Palgrave.

Preda, A. (2002). Financial knowledge, documents, and the structures of financial activities. Journal of Contemporary Ethnography, 31(2), 207-239

Rahmil, D.J. (2014). How is digital technology changing the labor market? Retrieved from Digital Society Forum on January 2019: https://digitalsocietyforum.orange.com/en/lesforums/274comment le numerique faitil evoluer le marche du travail

Rita K. Almeida Carlos H. L. and Corseuil Jennifer P. Poole (2017). The Impact of Digital Technologies on Worker Tasks: Do Labor Policies Matter? IZA Institute of Labor Economics.

Robert Grundke, Luca Marcolin, The Linh Bao Nguyen, Mariagrazia Squicciarini (2018). Which skills for the digital era?: Returns to skills analysis. OECD Science, Technology and Industry Working Papers, http://dx.doi.org/10.1787/9a9479b5-en

Sabbagh, K., Friedrich, R., El-Darwiche, B., Singh, M., and Koster, A. (2013). Digitization for Economic Growth 
and Job Creation: Regional and Industry Perspectives, 35-42.

Saunders, V., and Zuzel, K. (2010). Evaluating Employability Skills: Employer and Student Perceptions. Journal Bioscience, vol.15(2). Retrieved July 21, http://www.bioscience.heacademy.ac.uk/journal/vol15/beej-15-2.pdf.

State Information Service (2018). IMF hails strong growth in Egypt's labor market. Retrieved January 17, 2019 http://www.sis.gov.eg/Story/132348?lang=en-us

Terzioglu, A., Kamen, M., Boehm, T., and Stephan, A. (2017). IT unbounded: The business potential of IT transformation. Deloitte University Press.

The Organization for Economic Co-operation and Development (2015). Employment outlook. Retrieved on December 2018: http://ifuturo.org/documentacion/Employment\%20outlook\%202015.pdf

The Organization of Eastern Caribbean States - OECD. (2016). Self-employment rate. Retrieved from OECD on December 2018: https://data.oecd.org/emp/selfemploymentrate.htm

Walwei, U. (2016). Digitalization and structural labor market problems: The case of Germany. ILO Research Paper, 17, 1-31.

World Economic Forum (2016). Global Information Technology Report 2016. Retrieved from World Economic Forum: http://reports.weforum.org/globalinformation-technologyreport-2016/report-highlights/

World Economic Forum. (2017). Digital Transformation Initiative. Retrieved from World Economic Forum: http://reports.weforum.org/globalinformation-technologyreport-2016/report-highlights/ 